\title{
'Un engin de torture, une baïonnette à crochets; une arme blanche déshonorée': an historical-archaeological evaluation of the Sawback bayonets of the Deutsches Heer
}

\author{
Julian Bennett \\ Department of Archaeology, İhsan Doğramacı Bilkent University, Ankara, Turkey
}

\begin{abstract}
The Imperial German Army (Deutsches Herr) was unique among the combatants in World War One (WW1) in issuing to a proportion of its soldiers a bayonet whose blade back was fashioned as a saw. A common belief developed quickly among the Allies that these sawback bayonets were weapons specifically intended to inflict a particularly vicious type of wound. After setting out the origins of this class of weapon and explaining their real purpose, the two main types of sawback bayonet available to the Deutsches Heer during WW1 are then concisely described. Its reputation as a weapon of especial barbarity is outlined, along with an overview of bayonet use in combat between the mid-nineteenth century and 1918 , as evidenced by official sources, highlighting the lack of any specific contemporary references to the use of or the wounds caused by sawback bayonets. The article concludes by detailing the contemporary German sources relevant to its withdrawal from service use in 1917.
\end{abstract}

\section{ARTICLE HISTORY}

Received 11 September 2019 Accepted 12 February 2020

\section{KEYWORDS}

Sawback bayonets; Seitengewehre mit Säge; German Imperial Army; Deutsches Heer; bayonet wounds

\section{Introduction}

Bayonets make a frequent appearance among the artefacts discovered during agricultural activities and research and rescue excavations on the battlefield sites of the First World War (WW1). Moreover, for those specializing in artefacts of WW1, they are instantly relatable as items issued to all serving soldiers in the conflict, a conflict well within the family memory of many such researchers. From the artefactual point of view, those bayonets used by the Deutsches Heer or Imperial German Army provide the greatest variety of types, including examples with the blade-back fashioned as a saw. A commonly held view by the enemies of Germany at the time, and one still current today, was that these sawback bayonets were explicitly produced to cause particularly vindictive wounds. Thus, for example, on 19 December 2018, the British Daily Mail printed a news piece headed:

German WWI body armour and weaponry so barbaric it was banned under the Geneva Convention for inflicting incredible pain on soldiers is set to sell for thousands in auction ... 
Items include a German 'sawback bayonet' blade that was eventually banned ... One side had a lethal serrated edge that helped it to pull out a victim's insides (Petit 2018)

As such, the article - published just over a century after sawback bayonets were withdrawn from service with the Deutsches Heer - perpetuated a myth well established in France in September 1914. That is to say, the German sawback bayonet was 'Un engin de torture, une baïonnette à crochets; une arme blanche déshonorée', ${ }^{1}$ designed purposely to inflict an especially malicious rather than straightforward wound.

In reality, the sawback bayonet was a tool-cum-weapon with a long tradition of use in some European armies prior to WW1, although it is true that only members of the Deutsches Heer were issued with this between 1914 and 1918. The origins of the type lie in the mid-eighteenth century with the formation of dedicated artillery units and the need for clearing brushwood and the making of fascines for emplacing cannons and other purposes. Hence, the appearance in France of the Glaive de sapeur Mlle 1767, with its 48 or so single teeth spaced at 10 per $10 \mathrm{~cm}$ along the blade-back, these being 'set' like those in a cross-cut saw. In other words, as with this woodsman's tool, a near-vertical forward edge for a push stroke across wood and an angled rear edge to ease the pull-back, each tooth 'set' alternately left and right to create a groove ('kerf') to expel sap-laden sawdust and ease the passage of successive saw teeth without their clogging.

Similar models were adopted subsequently by other European armies. For example, the Russian 1827 Pioneer Sword; the Swiss 1842 Faschinenmesser ('fascine knife'); the Prussian 1855 Pionierfaschinenmesser ('Pioneer's fascine knife'), or Pfm.55; and the British Pattern 1856 Pioneer Sword. In 1865, though, the Prussian War Ministry (hereafter PWM) made the decisive step of making such a tool-cum-weapon fixable to a rifle. The result was the Pfm 65 (Franz 1994, 544-545), beginning the German love affair with the sawback bayonet. Other nations soon followed suit. For example, in Belgium, the 1868 Yatagan-scie ('yataghan [sword-bayonet] with teeth'); in Great Britain the Pattern 1867 bayonet and then the Pattern 1871 'Elcho' bayonet; and in the United States the 1874 'Rice Patent Intrenching Bayonet'. Of these and other sawback models, their specific purpose as tools rather than weapons was described best in a somewhat satirical account of the 'Elcho' bayonet published in advance of its adoption in limited numbers for service use:

This bayonet will serve to cut a sheep up into joints of mutton, to saw asunder the shinbone of an ox, or a three-inch plank of elm. (Anon 1869)

By the turn of the nineteenth century, however, only the German States, united in 1871 into the Deutsches Reich, and Switzerland, still issued sawback bayonets to their armies, and it is to those of the former that we now turn.

\section{The Sawback bayonets of the Deutsches Heer}

Article 63 of the Reichverfassung des Deutschen Reiches of 16 April 1871, the Constitution establishing Imperial Germany, authorized the creation of a unified army from the military forces of the 26 state entities in that federation. The article stated how this army was subject to Prussian decisions concerning its weaponry and uniform style and colours to create a fully integrated force in war-time. ${ }^{2}$ This insistence on a cohesive weaponry system 
marks the first stage in the history of the WW1 German sawback bayonet when in 1872, the PWM decided to arm all Pionierbataillone (Pioneer battalions) along with the Eisenbahn (railway), Train (supply) and Telegraph (communications) units, with the Jägerbüchse M.54 ('Hunter's rifle [model] 54'), and a sawback bayonet. Initially, this bayonet was one or other variant of the Pfm.65 (cf. Franz 1994, 538-543, 2000, 40-47; Carter 1994, 90-94), before the adoption in 1875 of the $P f m .71$ with its $48.2 \mathrm{~cm}$ long and $3.62 \mathrm{~cm}$ wide blade, and a sawback with 75 teeth, 38 on the right side, 37 on the left (cf. Franz 2000, 32-35 and 64-154; Carter 1994, 99-102; 269-275).

A more significant step in the history of the German sawback bayonet came in 1872 with the introduction into military service of the Infanterie-Gewehr 71 ('Infantry rifle 71'), or IG.71, followed in 1877 by its purpose-made bayonet, the Infanterie-Seitengewehr 71 ('Infantry sidearm $71^{\prime}$ ), or IS.71 (Carter 1994, 249). ${ }^{3}$ At first made in non-sawback form only, on 21 February 1879, Kaiser Wilhelm II ordered that a sawback version of this be produced and distributed among the various Infanterie-Regimenten, Jäger- and LandwehrBataillonen, and Füß-Artillerie (Heavy artillery) units on the basis of $6 \%$ per rifle (Carter 1994, 254; cf. Ehle 1981, 1/16), so becoming the first such tool-cum-weapon issued to units other than Pionierbataillone and the like. This sawback version, the IS.71 mit Säge ('with saw'), or $15.71 \mathrm{mS}$, shared the same blade form as the regular $1 S .71$, at $47 \mathrm{~cm}$ long and $2.8 \mathrm{~cm}$ wide, but with 22 'double' teeth along the blade back, i.e., 22 each side. No document survives to show how these $15.71 \mathrm{mS}$ were to be allocated among the individual units. However, the $6 \%$ figure matches closely the proportion of Unteroffiziere or middlerank NCOs in these units as with, for example, the 115 Unteroffiziere in an infantry regiment with a nominal fighting strength of 1,688 , and so $6.8 \%$ (Oberleutnant Hein 1901, 28-29).

After the introduction of the $15.71 \mathrm{mS}$, then aside from those sawback-only bayonets produced exclusively for Pionier and similar units, $6 \%$ of all bayonet types issued to the other regular units of the Deutsches Heer were of sawback form. It would be exceedingly tedious to list and describe each of the 11 or so bayonet types made subsequently and which - like the $I S 71 \mathrm{mS}$ itself - saw service with the Deutsches Heer during WW1. More germane here is to note how shortly after the start of that conflict, the entire infantry arm of the Deutsches Heer began to exchange its now standard sword-bayonet style S.98 without or without a sawback with the regular and the sawback versions of two specific bayonet types that by November 1918 greatly exceeded all others in terms of numbers issued, namely the S.98/05 and the S.84/98.

\section{The Seitengewehre $98 / 05$ and the S.84/98}

The more numerous of these two main bayonet types issued to German combat troops in WW1 was the S.98/05 (Carter 1984, 18-47) (Figures 1 and 2). Authorized for service in 1905 (Ehle 1981, 3/17), this had a distinctive machete-style blade, $37 \mathrm{~cm}$ long and $2.6 \mathrm{~cm}$ wide at the crossguard, before widening to $3.15 \mathrm{~cm}$ wide at $28.2 \mathrm{~cm}$ from the crossguard and then narrowing to the point, its similarity to a butcher's knife earning it the common name in English as the 'Butcher bayonet'. ${ }^{5}$ As with all other bayonets designed to fit the Gew.98, this lacked a muzzle ring. Secret German research in the $1870 \mathrm{~s}$ had shown how the traditional system used to fix a bayonet to a rifle via a muzzle-ring and mortise and tenon affected the rifle's accuracy when fired with a fixed bayonet (Cranz and Koch [1898]1899, 
768, and [1901]1902, 560, with 572-574). To eliminate this problem, in 1895, during trials of various new rifle prototypes, the Waffenfabrik Mauser concern of Oberndorf developed a new method of fixing a bayonet to a firearm by suspending from the rifle's forestock. This system used a longer bayonet bar and pommel slot with a smaller ring on the bayonet's upper crossguard that fitted over the cleaning-rod boss at the end of the forestock, so eliminating all contact between barrel and fixed bayonet. ${ }^{6}$ Further trials then demonstrated how the longer bayonet bar was able to carry the full weight of the bayonet with the rifle's cleaning rod sliding into a slot beneath the bayonet's pommel slot, this design being adopted for those bayonets fitting to the Gew.98 series of firearms. However, a muzzle 'rest', in the form of what official documents describe as a 'cut-out corresponding to the outer diameter of the barrel", was left on the upper surface of the crossguard, this being flanked by 'lappen' or 'lobes' (e.g., Ehle 1981 3/11 with 3/42), these usually being referred to in English as 'ears' (Figure 1). ${ }^{7}$

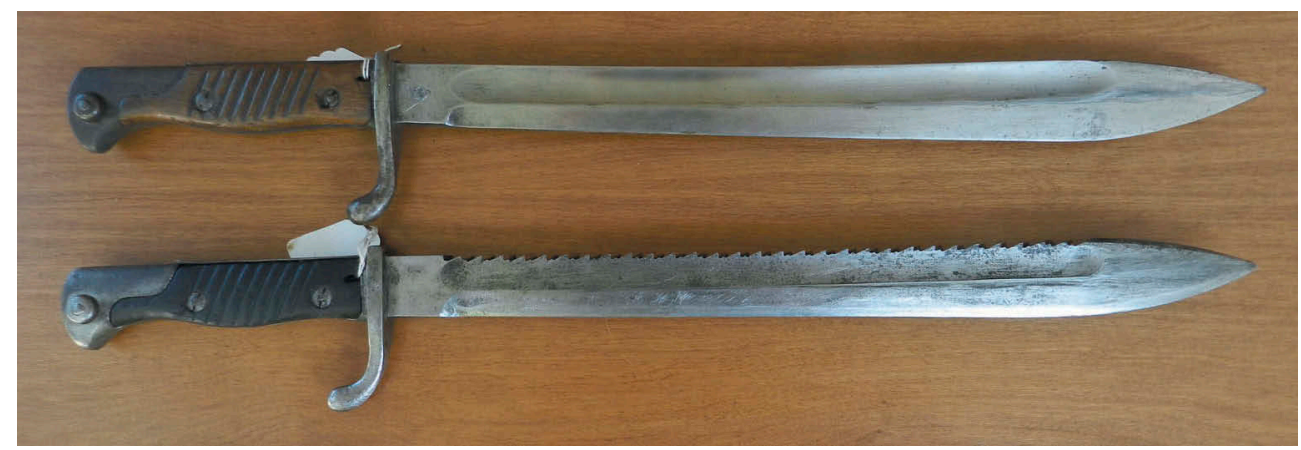

Figure 1. An S.98/05nA (above) and S.98/05nA.mS (below): author's photograph.

As originally introduced into military service, the standard S.98/05 was intended specifically for Fußartillerie and Telegraph units, while the S.98/05 mS, with 34 'double' teeth along the blade spine, was exclusively for Pionier and Eisenbahn formations (Ehle 1981, 3/17). However, between 11 September and 3 October 1914, the PWM decided that the $5.98 / 05$ should become the standard bayonet for all units except cavalry as it was an excellent 'Hiebwaffe' or 'chopping weapon' (cf. Ehle 1981 3/36). Indeed, on 11 December 1914 , to make up for an anticipated bayonet shortage to equip nearly 2.5 million extra field troops plus some 1.75 million others mobilized by the end of the year (Buchholz, Robinson, and Robinson 2014, 282-306, with 453-456), the PWM ordered an extra two million S.98/05, 800,000 each from Mauser Waffenfabrik of Oberndorf and the Deutsche Waffen-und Munitionsfabriken (although in the event the latter produced none), the remainder by the Suhl-based makers (Storz 2006, 363). It is clear, though, that the PWM made no allowance for shortages through battlefield losses, a shortage aggravated to some extent through an Imperial decree of 24 October 1916 that the S.98/05 be issued to all officers in front-line service in place of swords, the order being extended on 17 January 1917 to all officers regardless of their location (Ehle 1986, 277-278). Thus by 1918, some 40 manufacturers had been involved in producing S.98/05 in both non-sawback and sawback form for the Deutsches Heer, many of them firms better known for making 
sewing machines, bicycles, knives, scissors, and the like (Carter 1984, 64-91, for an accessible list of the known makers, as updated by Vorontova and Vorontova 2015, 102-382). Furthermore, to judge from their blade-spine markings, ${ }^{8}$ the peak years when the greatest number of firms was involved in making S.98/05 were 1916 and 1917 (Carter 1984, 91) (Figure 2).

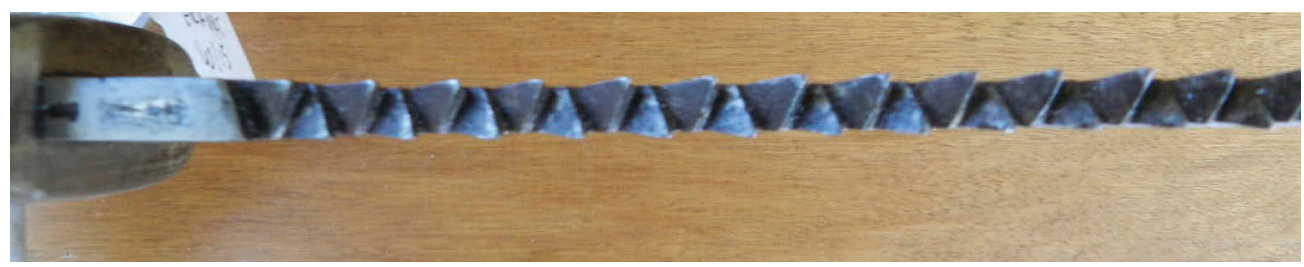

Figure 2. Detail of the sawteeth on the second bayonet in Figure 1: author's photograph.

Before this enormous expansion in the numbers of S.98/05 makers took place, the PWM decreed three significant changes to its original production specifications. The first, apparently initiated on 13 July 1915 (Storz 2006, 364), but not formally announced by the PWM until 3 September 1915, was that all newly-made S.98/05 be supplied with a Schutzbleche or metal flash guard on the back of the hilt to prevent the wooden grips from charring when used with the shorter muzzled Kar.98 (Ehle 1981, 3/ 37). The second, which accompanied the September instruction to fit the Schutzbleche to all S.98/05, was that the lappen or 'ears' on the crossguard be reduced to little more than stubs (Ehle 1981, 3/37; Storz 2006, 364), probably to eliminate the barrel vibration affecting accuracy when the Gew.98 and Kar.98 were fired with a fixed bayonet. Be that as it may, those $5.98 / 05$ without these adaptations, that is to say with no flash guard but with 'high ears', are referred to by collectors as the S.98/05aA ('alte Arte' = 'old model'), while those with the flash guard and 'low ears' are known as the $5.98 / 05 n A$ ('neue Arte' = 'new model'). ${ }^{9}$ The third change, announced on 16 September 1915, was that the blunt false edge forming the last $4 \mathrm{~cm}$ of these bayonets was to be sharpened (Ehle 1981, 3/19; Storz 2006, 364-365) (Figure 3).

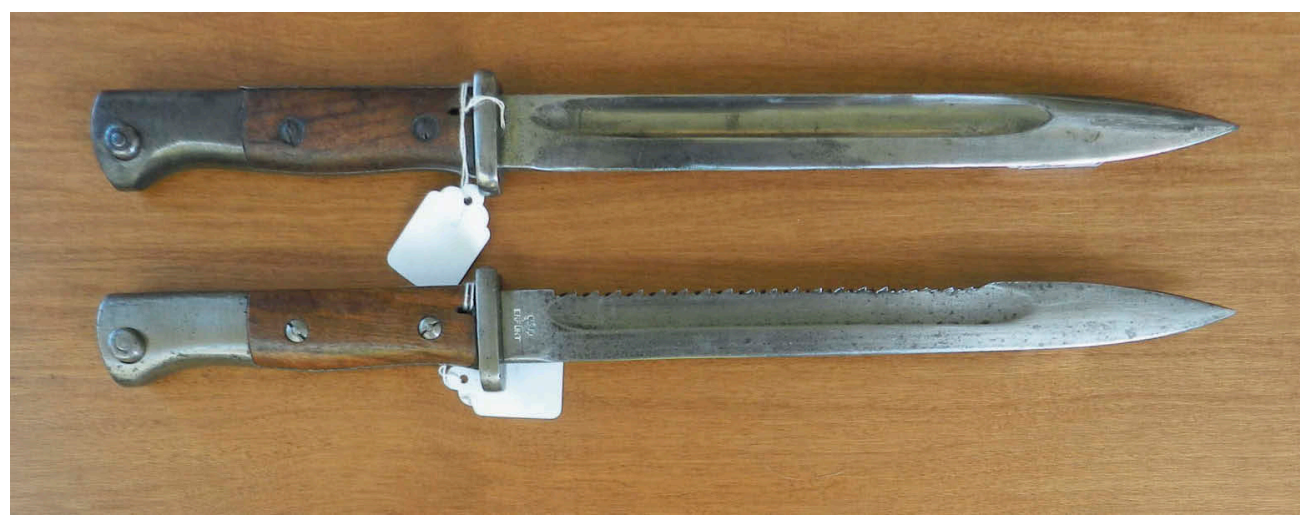

Figure 3. An S.84/98nA (above) and S.84/98nA.mS (below): author's photograph. 
The second most common type of sawback bayonet issued during WW1 to the Deutsches Heer is known to collectors as the S.84/98nA (Figures 3 and 4). This was, in fact, the third-generation version of what began life as the $15.71 / 84$, the first-ever knifetype bayonet in military service. ${ }^{10}$ Approved originally for service use in 1886 (Carter 1991, 9), the regular and sawback versions of this progenitor shared a $25.2 \mathrm{~cm}$ long and $2.7 \mathrm{~cm}$ wide blade, the $15.71 / 84 \mathrm{mS}$, having 16 'double' teeth along the blade-back (Franz 2001, 92-176). On 29 March 1909, though, an order was issued that the $5.71 / 84$ was to be rehilted and their muzzle rings removed for fitting to the Gew.98, this second-generation version becoming known officially as the S.84/98 (Ehle 1981, 2/12-13). Interestingly enough, this order resulted in the Bavarian Ordnance Department reporting that of their 102,343 examples of the $5.71 / 84,6,768$ were of sawback form (Ehle 1981, 2/12); thus, $6.61 \%$ of the total, close to the requirement that sawback bayonets should constitute $6 \%$ of those available to regular infantry units (Figure 4).

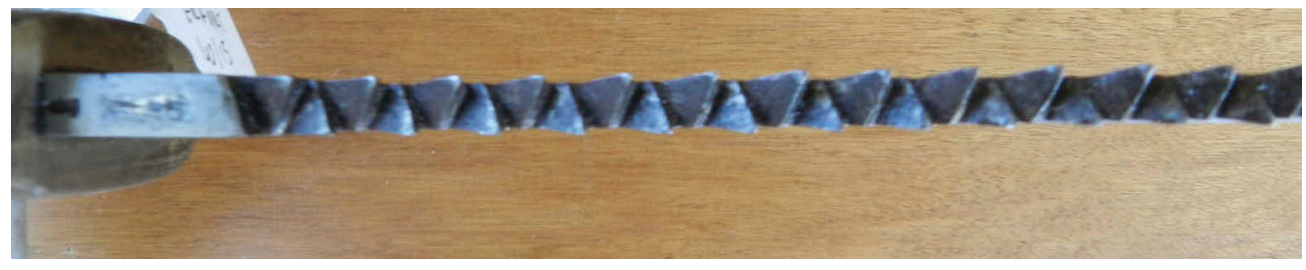

Figure 4. Detail of the sawteeth on the second bayonet in Figure 3: author's photograph.

On 9 November 1914, Kaiser Wilhelm II decreed that cavalry units, hitherto armed with sabres, degen (their thrusting swords), lances, and carbines, as suited their primary role as mobile formations, now were to be supplied with $5.84 / 98$ for fixing to the latter weapon (Ehle 1986, 266). ${ }^{11}$ This presumably came about in recognition of how cavalry could be employed as ad hoc infantry as trench warfare set in along the Western and Eastern Fronts. It also resulted in the introduction of the third generation of this bayonet type, a purpose-made version with identical blade dimensions to the original $5.71 / 84$ as converted to become the $S .84 / 98 .{ }^{12}$ No documentation is known to survive for the official introduction into service of this third version, referred to by collectors as the S.84/98nA ('neue Arte') to distinguish it from its immediate precursor, which they designate as the $5.84 / 98 a A$ ('alte Arte'). ${ }^{13}$ On the other hand, the earliest blade-spine markings for these $5.84 / 98 \mathrm{nA}$ indicate that their production began sometime during 1915. As it is, a document issued by the Bavarian War Ministry on 16 January 1915 shows that their cavalry units were then armed principally with all-steel 'Ersatz' bayonets (Ehle 1986, 261), while another order reveals cavalry on the Eastern Front were still being issued with these as late as 10 February 1915 (Storz 2006, 365). It is apparent, though, that the Bavarian Cavalry were using wooden-gripped bayonets by 23 March 1915, when their Ordnance Office ordered some 5,000 Schutzbleche from the PWM for these (Storz 2006, 366). As we have seen already, Schutzbleche were required for fitting to wooden-gripped bayonets fixable to carbines. Thus, even though the Bavarian cavalry were at this time 
using a mixture of wooden gripped bayonets (Storz 2006, 365), given how there are no reported examples of S.84/98aA with Schutzbleche while all the earliest dated S.84/ $98 n A$ have this fitting, the latter model clearly entered production in the first few months of 1915 (Figure 5).

Several early S.84/98nAmS are marked for cavalry units, indicating their need for a toolcum-weapon for clearing brushwood and the like, pointing to their employment in static warfare, if on an ad hoc basis only. It was presumably in this way that other units of the Deutsches Heer became familiar with this bayonet and, we must assume, soon recognized the clear advantages of its short length in trench warfare, especially for night-time patrols and raiding parties. Thus, by 29 March 1915, by official order of the PWM, the S.84/98 in non-sawback and in sawback form had become the weapon of choice for Pionier units, each company being supplied with ten S.84/98, or, alternatively, the kS.98 ('kurzes Seitengewehr 98' = 'short sidearm 98'), a sawback knife bayonet introduced in 1902 initially for machine gun units only (Ehle 1981, 3/33; Carter 1991, 131-139). What is more, on 8 May 1915, it was decided that regular infantry units also were to be supplied with the S.84/ $98 n A$ (Storz 2006, 365), presumably likewise for its ease of use by trench raiders, as was in fact confirmed by an order issued by the PWM on 18 January 1917, that the S.84/98 was to be issued to all 'Sturm-Bataillone' (Ehle 1981 3/33). However, although some 20 makers were involved in the production of the S.84/98nA from 1915-1918 (Carter 1991, 178-182), demand always exceeded supply. For example, the $15,000 \mathrm{S.84/98nA}$ distributed to Bavaria in June 1918 had all been issued by that September when a request for a further 20,000 met with the response that only 10,000 could be sent as stocks were exhausted (Storz 2006, 367) (Figure 6).

Without a thorough scouring of any records that might survive, it is impossible to quantify precisely how many S.98/05 or S.84/98nA of non-sawback and sawback types were distributed to the Deutsches Heer before 11 November 1918. In May 1917, though, the Bavarian War Ministry reported to the PWM it possessed 146,014 plain S.98/05, and 29,981 S.98/05 mS, along with 11,530 S.84/98 and 999 S.84/98 m.S., meaning that sawback versions represented, respectively, $17.04 \%$ and $7.97 \%$ of the total for each type (Storz 2006, 373). Official figures compiled for Saxony on bayonets supplied to their army between the start of WW1 and 31 March 1918, on the other hand, give 453,387 regular $5.98 / 05$ and $89,287 \quad 5.98 / 05 \mathrm{mS}$, and 48,319 regular $5.84 / 98$ compared to 13,058 S.84/98 mS, thus $16.45 \%$ and $27.02 \%$, respectively (Storz 2006, 373). The figure for Bavaria in May 1917 equalling 7.97\% of the numbers of $5.84 / 98 \mathrm{mS}$ supplied to that entity during WW1 matches reasonably well with the general rule that $6 \%$ of each bayonet-type was to be of sawback form. The 'surplus' over the nominal $6 \%$ for this type of bayonet held by the Saxon Army, and that of the S.98/05 in service with both Bavaria and Saxony, might be explained to some extent by no distinction being made between the type of unit these bayonets were issued to, whether to Pionier and similar units or to others. But, however we explain these divergences from the $6 \%$ rule in the number of sawback bayonets held by each of these armies, it remains clear that, Pionier and associated units apart, sawback bayonets, with their long history as tools-cum-weapons, were in relatively limited use among the various units of the Deutsches Heer. This reality, though, was of no consequence, to those eager to damn the 'Boche' as the neutrality of Belgium was ignored, and German forces marched through Flanders and into France, as we shall now see (Figure 7). 


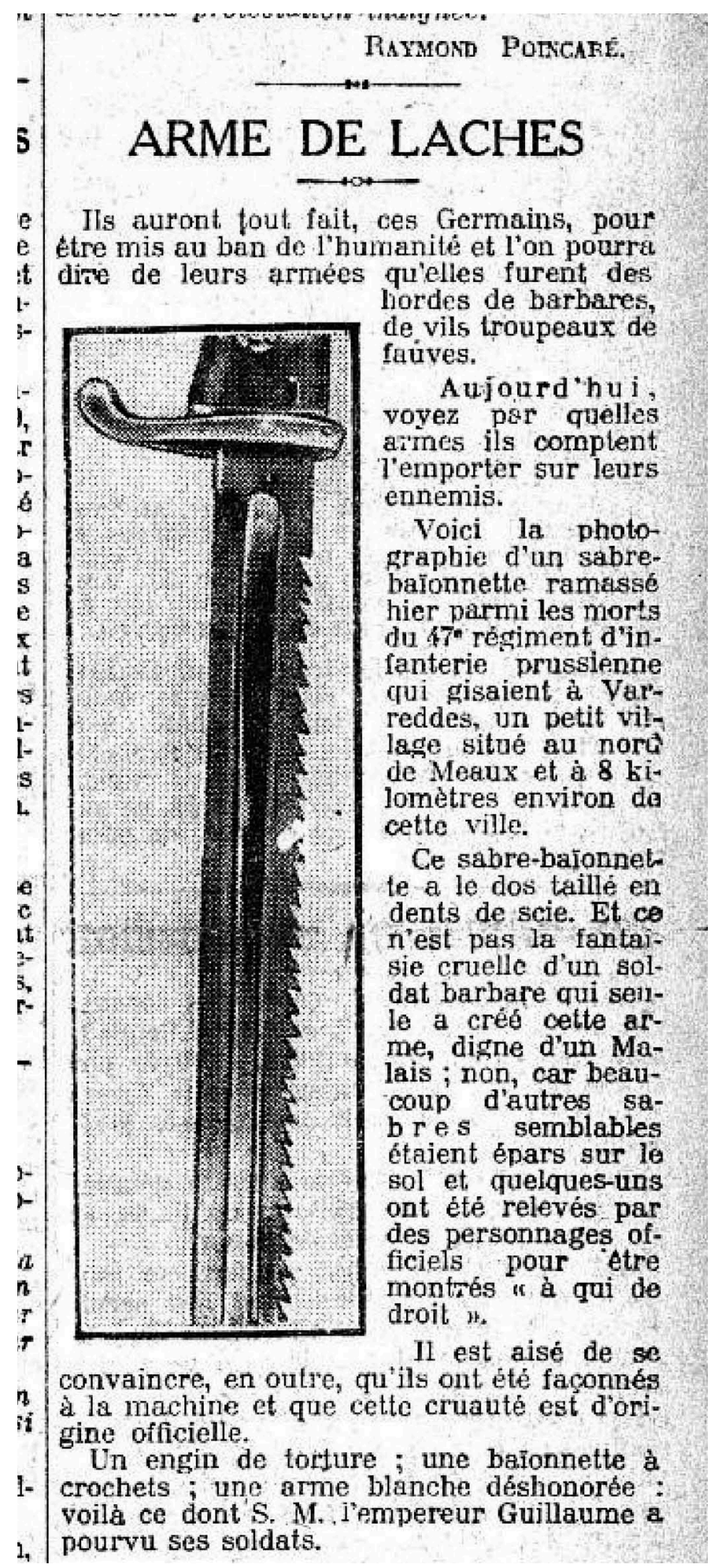

Figure 5. An 'ARM(E) DES LACHES', an S.98 mS, as shown in Le Matin 13 September 1914: author's photograph. 


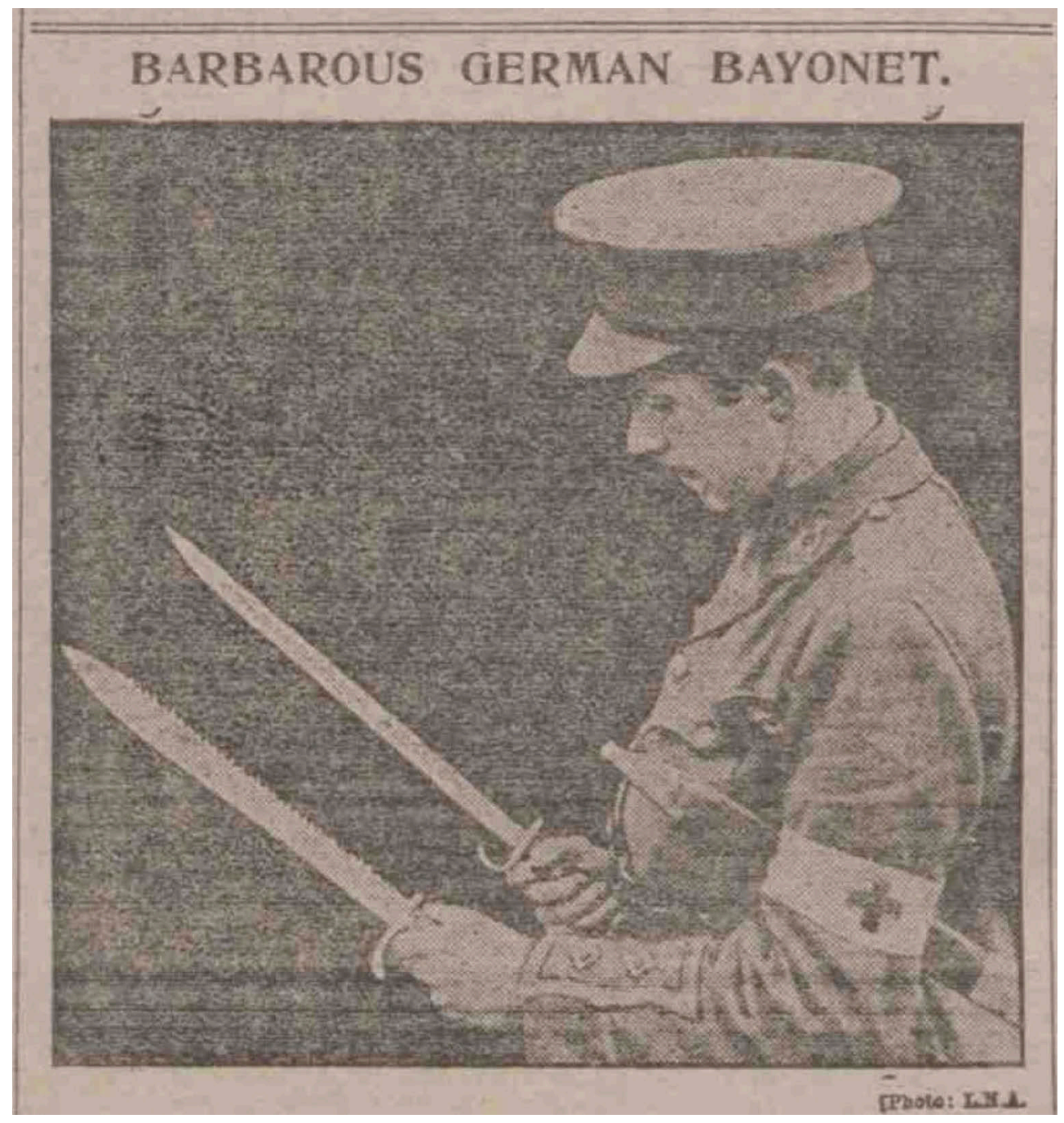

Figure 6. The 'BARBAROUS GERMAN BAYONET', an S98/05aAmS as shown in The People 27 September 1914: author's photograph.

\section{'un engin de torture'?}

To be sure, the advance of German forces through neutral Belgium and into France in August 1914 saw numerous episodes of brutality towards wounded enemy combatants and civilians also, old and young, several such events involving the use of the bayonet. ${ }^{14}$ It is also a fact that many of those in France and Flanders who suffered this way did so because they were, or were believed to be, francs-tireurs or their protectors, resulting in the 'francs-tireurs myth complex' (Home and Kramer 2002, 129-139; Lipkes 2007, 548-551, for a rebuttal of the thesis). There is also the fact that brutal punishment was inflicted sometimes on the relevant local civilian population in a straightforward reprisal for their military forces forcibly resisting German progress through already occupied territory (e.g., 


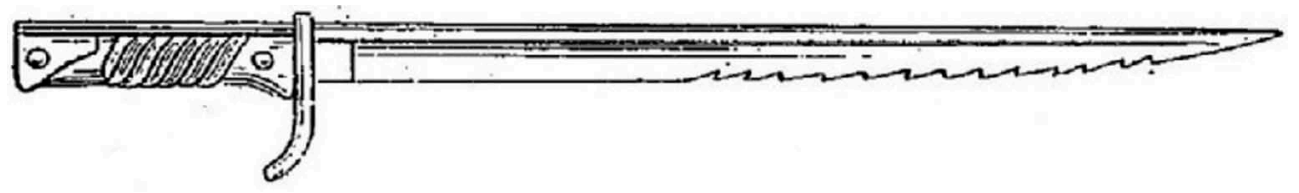

Frg. 7.

La bä̈onnette à dents de scie des Boches. Il n'est besoin d'être nï menuisier ni charpentier pour se rendre compte, d'un coup d'œil, que cette arme ne peut en aucune manière rendre de services $\dot{a}$. un travailleur d'infanterie qui l'utiliserait en guise de scie. Les . dents coupantes dont elle est munio sont trop grosses et trop. irrégulières pour pouvoir sectionner les fibles du bois autrement qu'en les arrachant et les dilacérant. Par contre, la baïonnette à dents de soie est une arme terrible, qui fait des blessures. effroyables et provoque dans les tissus des désordies irréparables.

Figure 7. A fantasy sawback bayonet illustrated in Mare 1916: author's photograph.

Lipkes 2007, 51 with 543). Hence, the noticeable fall-off in such events once the process of static occupation began (e.g. Home and Kramer 2002, 77-78).

Such outbreaks of German brutality against local civilians in France and Flanders made little impact in the English press for August and September 1914. It was more concerned with 'the vandalizing of monuments of Western Civilisation', such as the burning of the library at Leuven, or shell damage to Rheims cathedral, etc. (Home and Kramer 2002, 218-220; Lipkes 2007, 15 with 616-617). Attitudes began to change, though, as the first reports of the official Belgian Commission d'Enquête sur les Violations des Règles du droit des Gens, des Lois, et des Coustomes de la Guerre were discussed in the Houses of Parliament on 15 September 1914 (Lipkes 2007, 44 with 690). That December, a British parliamentary committee was formed to examine these allegations, their report, published in early 1915 (Bryce 1915), focussing on the period 19-26 August seen as best exemplifying the alleged innate barbarity of the German soldier (e.g., Lipkes 2007, 13).

By that time, propaganda intended to justify the British declaration of war against Germany by painting the Deutsches Heer as an army involved in relentless and the mass indiscriminate slaughter was well developed (cf. Home and Kramer 2002, 231). Incidents that helped ripen the incipient picture of German brutality against Belgian and French combatants and civilians alike during August-September 1914 had been quickly picked up by reporters representing the popular press of the Allied countries (e.g., Morgan 1915, passim). Any such events supporting this picture as they were learnt from refugees, even if usually without any reliable corroborating evidence, proved 'good copy', and so soon made their way into public consciousness via the popular press. Typical of these was the tale of the little boy of Magny in France, allegedly executed out-of-hand for pointing his toy gun at German soldiers (Home and Kramer 2002, 207). However, another story that soon became widespread was the German use of the sawback bayonet. 
For example, on 13 September 1914, under the heading 'Arme delaches' [A weapon for cowards], Le Matin published a photograph of an $5.98 \mathrm{mS}$ on its front page along with the following:

These Germans have done everything to deserve being banished from humanity and their armies are vile beasts. We see this today from the weapons they rely on for overcoming their enemies. Here is a photograph of a sword bayonet picked up yesterday among the dead of the 47th Prussian Infantry Regiment at Varreddes, a small village near Meaux. This sword bayonet has the blade back formed into sawteeth. This is not the fantasy from cruelty of a barbarian soldier who created personally this weapon - worthy of a Malayan [sic] - as a lot of other similar weapons were scattered on the ground there ... It was fashioned by machine and its cruel nature has an official origin. An instrument of torture, a bayonet with teeth, a blade without honour [Un engin de torture; une baïonnette à crochets; une arme blanche déshonorée]: this is what his Majesty the Emperor William has given to his soldiers (Figure 5$)^{15}$

To be fair, this report generated a response printed the very next day, albeit relegated to page 2, pointing out that according to the current semi-official French sources on German weaponry (Roy 1914), the sawback version of the 'Sabre-baïonnete Modèle 1898-1902 (Infanterie-seitengewehr)' was issued as per regulations to sous-officiers alone of the regular army, while the sawback model 'S[eiten].G[ewehr].98/05' was carried by the Pionier and Eisenbahn troops specifically. It also stressed how the sawback bayonet, or 'La baïonnette $a$ scie', as used by the German army was a form of 'Faschinen-messér (couteau à fascines)', which 'should, in principle, only be used for making earthwork defences, [or] for their destruction, etc.', although another correspondent reported that on 5 August a French sous-officier in Belgium had found such a weapon on the body of a 'hussard Saxon' there.

Even so, the reputation of the sawback bayonet as a 'weapon of the cowardly', continued to be highlighted in the French press, as with an editorial in Le Matin for 20 September 1914. Headed 'les deux mains' ('Both hands'), it noted an alleged incident where a sawback bayonet (la baïonnette à dents de scie) was used to amputate the hands of a young woman and an infant. This was, in truth, an early example of the 'severed hands' myth that became a popular image of German brutality in Belgium. The question does arise, though, as to what extent this was counter-propaganda to the pre-War allegations of like amputations inflicted on native employees of the Belgian Congo Company before WW1 (Home and Kramer 2002, 202-204 with 223).

Be that as it may, stories along the lines of Le Matin les deux mains almost certainly gave life to the belief that the German sawback bayonet was a weapon that, if not explicitly designed with barbarous intent, was certainly employed as such. Thus, for example, a report in the popular British newspaper The People on 27 September 1914, a month or so after the Battle of Mons, denouncing the use of sawback bayonets by the Deutsches Heer in the most strident terms. Beneath the heading 'Barbarous German Bayonet' was a photograph of an RAMC subaltern holding in his right hand a British Pattern 1907 hooked quillon bayonet and in his left a S.98/05 mS. (Figure 6), and below that a text noting how:

Every law of war is being broken by the Germans, whose latest act of barbarity is the use of saw-backed bayonets, which are prohibited by the Convention to which Germany is a signatory. ${ }^{16}$ This gruesome weapon ... because they rip and tear bone and flesh, are forbidden by the laws of war.... Many people agree that if the object of war is to kill men, 
how they are killed makes little difference. But civilian Powers do not assent to that, and certain methods of warfare and certain weapons are forbidden.... this saw-bayonet so tears the flesh that it cannot heal, and splinters the bone

A French pamphlet published in 1916 developed the theme, making much of the German use of 'unfair' weapons in the war such as the sawback bayonet, along with others for which there is no evidence to the claim, as with dum-dum bullets, poisoned shrapnel balls, etc. (Marre 1916, 31-32). Regarding the sawback bayonet it noted how it was intended:

... (T)o play the dual role of hand saw and weapon of slaughter, according to the way it is used. In reality ... when fixed to a rifle, it causes wounds much more serious than those of ordinary bayonets, because it produces a tearing effect when the soldier pulls it from the body of an enemy. ... [Moreover] The order is given to all the men never to leave for an assault without having repeatedly pressed the blade into soft ground so that the teeth retain particles of earth that can infect wounds inflicted on the enemy.... It is not necessary to be a carpenter or woodworker to realize, at a glance, that this weapon cannot serve as a saw. The sharp teeth with which it is equipped are too large and too thick, and wood can be cut only by tearing the fibres.... this bayonet is a terrible weapon, which makes frightful wounds and causes irreparable tissue damage. [A French unit] ... observed that all 'the sawback bayonets of one troop had been coated with faeces'. It is not necessary to stress what horrendous complications of septicaemia and pus-laden infection would be sustained by those wounded by these. Every prisoner found to be carrying ... a bayonet with a deliberately infected blade [should] be considered a bandit and, as such, hanged high and short, without judgment (Marre 1916, 37). ${ }^{17}$

The text was accompanied by a figure of what can best be called a fantasy bayonet with the saw teeth on the wrong side of the blade and resembling in no way whatsoever any sawback bayonet in German service (Figure 7). It is difficult to see how such a mistake could be made unless it was a deliberate attempt at 'fake news', to advertise further the infamy of the hated 'Boche' among citizens who might never see the actual weapon.

This theme of the 'barbarous German bayonet' was also broadcast in the United States of America via an anonymously authored series of articles in 1917 initially published in the New Yorker Volkszeitung, subsequently translated and printed in book form (Koetggen 1917). These articles purported to be written by a German soldier who entered Belgium with the $1^{\text {st }}$ Company of the Pionier Bataillon Nr. 30 at the beginning of the war but who allegedly deserted eleven months later and fled to the United States on account of the various German atrocities he had witnessed, coupled with what he asserted was military incompetence at the highest level and the widespread cowardice of the officer class. In Chapter 9 of the book, the anonymous Pionier describes how as a 'sapper' he was issued with:

... a bayonet which must not be fixed to the rifle according to international agreement, because the back of that bayonet is an extremely sharp steel saw ... In times of peace the sapper never does bayonet practice, the bayonet being exclusively reserved for mechanical purposes. But what does militarism care for international law! ... Humanity was a jest when one saw an opponent with the toothed saw in his chest and the victim, who had long given up all resistance, endeavouring to remove the deadly steel from the wound. Often that terrible tool of murder had fastened itself so firmly in the victim's chest that the attacker, in 
order to get his bayonet back, had to place his foot on the chest of the miserable man and try with all his might to remove the weapon.

It must be noted, though, that the veracity of this work is contested. Some accept it as a piece of historical writing (e.g. Meredith 2004, 49-63), but the translator and publisher of the work, Julius Koettgen, was prominent in socialist activities and anti-war matters in general also (e.g. Koetggen 1916), and so there is good reason to believe he was acting as an agent provocateur. Thus, it might well be a skilled piece of propaganda using known details of German units operating in Belgium in 1914-1915 to highlight the 'barbarity' of the German army in an attempt to swing American public opinion in favour of joining the allies.

By contrast, the use of the sawback bayonet by the Deutsches Heer gets no mention in the most commonly cited English-language 'official' accounts of German atrocities in Belgium and France in 1914 and early 1915. That is to say, the summary by Cooreman (1915) of the first Belgian Commission d'Enquête reports, the testimony provided to the Bryce Commission (Bryce 1915), and the account based on soldiers' stories published by Bryce (1915). In fact, the first and the last of these three mention the use of the bayonet as a weapon of Germanic brutality exactly twice, and while the Bryce Commission referenced some forty episodes of bayonet-related behaviour contrary to the current 'Rules of Law', none of the three comment specifically on the use of the sawback bayonet. Nor, for that matter, is it mentioned in a near-contemporary popular account of the experiences of soldiers and others serving with the BEF in 1914 and early 1915 (Ogilvie 1915). But, 'Truth is the first casualty in wartime'. Despite the lack of reference to the use of the sawback bayonet in these official or even 'first-hand' accounts, the weapon had already been fetishized by the popular press and others. It was done to support claims of inherent German brutality contrary to the 'normal' rules of war, and so arouse wider public indignation against Germany and its soldiers while also vindicating Britain's support of 'poor little Belgium'. The fact that Belgium was a small country with one of the larger European armies for its size, armed with the most modern of weaponry - ironically much of it German-made - and whose monarch and a series of private investors had held a part of Africa, the Belgian Congo, as a slave plantation, was ignored in favour of a degree of believability in German atrocities. Likewise, the use by their French allies of the quadrangular-sectioned needle-like 'Rosalie' bayonet, a weapon akin to a stiletto, capable of deeply penetrating clothing and a man's internal organs, was quietly overlooked in the search for means to paint the blackest picture possible of the 'Hun'. In this war of propaganda, recounting the story of the 'barbarous German bayonet' in popular newspapers such as The People, especially when picturing an example of the weapon in the hands of a British Army officer wearing a Red Cross brassard, proved exceptionally effective.

\section{Bayonet combat in WW1}

Given the lack of any first-hand official accounts of the sawback bayonet used as a 'barbarous' weapon, it would be as well to review the frequency of bayonet fighting in WW1. As Stone has commented (Stone 2012, 887-888), the rarity of such combat as represented by combat casualties in any 'modern' war has long been an established fact. 
In direct contrast to a casualty rate of $15-20 \%$ by bayonet in the period $1800-1860$ (Stone 2012 , 888), developing battlefield tactics using long-distance artillery and rifles with an accurate range of 300 metres or more had greatly reduced the exposure of infantrymen to one-on-one combat using edged weapons. Already by the American Civil War, sword and bayonet wounds amounted for a mere $0.3 \%$ of recorded Union casualties (Stone 2016, 888). Something similar was evidently experienced during the Russo-Japanese War of 1904-1905, a war notorious for establishing the value of the bayonet in 'modern' warfare, in that it involved frequent bayonet combat against trenches and other prepared defensive positions, often at night (e.g. Balck 1911, 382). ${ }^{18}$ Such at least might be gleaned from a summary prepared by an official American medical observer, Major C. Lynch, who stated that bayonet and sword wounds were so rare he had no data on these, and that wounds caused by the Russian bayonet, with its quadrangular-sectioned socket blade, were 'not severe', if, perhaps, liable to suppuration (cf. Schulyer et al. 1906, 193-194). Indeed, a later analysis of the casualties in that conflict suggested that those for all classes of edged weapons were around 2.5\% (Wintringham and Blashford-Snell 1973, 146-7). To some extent, we must, of course, bear in mind that many a person incapacitated by a bayonet thrust or other weapon might then have been bayoneted to death, a not infrequent occurrence observed in the Russo-Japanese War and WW1.

With specific regard to WW1, bayonet charges and 'death by bayonet' are referenced relatively often in the private diaries and subsequently published writings of some who participated in that war, and sometimes in the official histories of the units involved also. Yet insofar as the official medical histories are concerned, bayonets were responsible for a surprisingly small number of recorded casualties. This could, to some extent, be due to the effect on the morale of an opponent faced with a bayonet charge, the impassioned nature of the charge being probably far more important in causing the enemy to retreat rather than the possibility of the physical harm he might receive. Be that as it may, a Medical Inspector of the French Army in August-September 1914 observed that wounds from 'cold steel' - thus the sword, the lance, and the bayonet - 'occur in the proportion of 5\%' (Delorme 1914, 2, with 71, and 128). True, as the same author noted, this figure of 5\% was above the $0.6 \%$ of all casualties caused by 'cold steel' in the 1870 Franco-Prussian War. However, he was writing of all classes of 'cold steel' wounds at a stage when WW1 was still in an essentially fluid state, with cavalry pursuits and charges and the like. It is often forgotten that the first German combatant to meet his death in action with British troops in 1914 was allegedly an Uhlan who died of a sword-thrust inflicted by Capt. C. Hornby, $4^{\text {th }}$ Royal Irish Dragoon Guards, at Le Casteau on the morning of 22 August. $^{19}$

This low frequency of bayonet wounds in 'modern' warfare might well explain why British medical staff saw no need to maintain a separate account of bayonet casualties during WW1 (Wintringham and Blashford-Snell 1973, 147). Thus, owing to the lack of adequate records, only a single detailed analysis could be made subsequently for the frequency of bayonet wounds in that war, namely for the casualties incurred during the Third Battle of Ypres (Passchendaele) on 21 and 27 September 1917 (Macpherson 1924, 170-171). Fought over a landscape crisscrossed with trenches, marked with bunkers and ruined villages, of an overall total of 10,789 wounded on the first day, mainly by shellfire, 3,027 were admitted with what might be called close combat injuries, that is to say, 2,933 by the bullet, 17 by the bayonet, and 77 from hand grenades. Of the 2,932 casualties listed on 27 September, the majority again suffering from shell splinters and sherds, 634 had 
close combat wounds, with 600 from bullets, eight from bayonets, and 16 from hand grenades. In other words, bayonet wounds represented $0.56 \%$ and $1.26 \%$, respectively, of those two days in combat. The general impression that bayonet wounds were in the minority, at least among those admitted to casualty stations, is confirmed by figures compiled for British wounded at the end of WW1 from what was presumably a limited set of data. This concluded that overall, of 212,659 wounded men admitted to casualty clearing stations during 1914-1918, bayonet wounds formed $0.32 \%$ of those hospitalized (Mitchell and Smith 1931, 40, Table 15). By comparison, of the 224,098 men of the USA Expeditionary Force hospitalized for wounds, 235 only were bayonet casualties, and so a mere $0.1 \%$ of their hospitalized had sustained bayonet wounds, the far greater majority having suffered from gas-poisoning (Gilchrist 1928, 19 with Chart VII).

It would seem, though, that the nature of the terrain involved had some effect on the number of bayonet casualties. For example, during the 1912-1913 Balkan Wars, fought principally over a hilly landscape characterized by ravines and the like, the numbers of those wounded by bayonets represented $10 \%$ of the total casualties, such wounds being mainly to 'the body, the abdomen, [and] the upper part of the lower limbs' (Delorme 1914, 1). A link between the type of terrain and a higher incidence of bayonet casualties was certainly observed in the ANZAC sector at Gallipoli, where combat 'involved fighting up gullies, cliffs and ravines covered with thick scrub', a 'confused hilly country without roads or tracks, up ravines covered with thick scrub, and on to the precipitous ridges and peaks' (Macpherson and Mitchell 1924, 11, with 13-14). The result was: 'A comparatively large number of the wounds [here] were bayonet wounds', whereas 'Bayonet wounds were rarely seen in the medical units in other theatres of war' (Macpherson and Mitchell 1924, 31-32). Allowance must also be made to the skill of the Ottoman army in bayonet fighting at Gallipoli, where many Australians were killed by a bayonet 'cut upwards' to the extent that medical staff 'never dressed a bayonet wound' as it was 'always fatal' (McGill 1919, 105-106).

Evidently, the terrain at Gallipoli could easily bring advancing attacker and retreating defender in surprisingly and unanticipated close contact, with what Stone $(2016,1024)$ described as 'an explosion of hyper aggressive behaviour'. We might, for example, envisage a scenario in which two combatants, usually holding their rifle and fixed bayonet at waist height, having found themselves suddenly in a situation that restricted manoeuvrability, chose the bayonet over the bullet, if not already advised to do so during surprise attacks. Such is in fact clearly indicated by a letter written in August 1915 by a member of the AIF, who noted that:

the country was nothing but hills and gullies covered thickly with small bushes behind which the Turks would hide and try and put up a bit of a stand until we routed them out with a bayonet. We were not to fire a shot - all work to be done with the bayonet (Henry 1915)

In other words, fighting in the confused and overgrown terrain of the ANZAC area could result easily in the on-site observation that 'A comparatively large number of the wounds were bayonet wounds' (Macpherson and Mitchell 1924, 31).

There are, of course, problems in relating these casualty figures to actual battle experience. To begin with, the British and Commonwealth forces did not adopt a systematic index card system for recording wound types and numbers until 1917, just in time for Third Ypres (Anon 1932, 91). Moreover, when they did so, bayonet wounds were 
typically listed under 'Miscellaneous' as seen from the 'Admission and Register book' for No.3 Casualty Clearing Hospital (Imperial War Museum Catalogue ref: MH106/279). This notes the vast range of injuries dealt with by army medical units and under Section XIV, almost at the end, gives 'Bayonet, Wounds of (structure or organ to be noted)'. Secondly, we cannot know how many men wounded by a bayonet may have been taken prisoner. Finally, we cannot determine from the data as published how many of those hospitalized with bayonet wounds may have received these by accident. This was probably not that uncommon: of 393 US Army soldiers wounded in the WW2 New Georgia-Burma campaign, three only involved bayonet wounds, two of them accidental (Beyer 1962, 6).

Most seriously, however, we have to consider that recorded bayonet wounds, as in numbers of treatable casualties, are not necessarily a good guide to the use of the bayonet in battle and the resultant number of deaths and injury. This was stressed already by the mid-nineteenth century, when in one of his lectures, G.J. Guthrie (1848), an army surgeon in Wellington's Peninsular Campaign, observed: 'it rarely happens that many are hurt by the bayonet, but if they are, they are killed outright and do not come under the observation of the surgeon'. Likewise, F.A. Pottle, a medick serving with the AEF, in France noted:

So, too, a bayonet would be likely to make a clean wound, which, if it did not kill a man outright, would probably not make much trouble. It is hard to say, for we had almost no experience with the treatment of bayonet wounds. Of the hundreds of cases which I recorded myself, I remember but one bayonet wound, and that was accidentally inflicted. I suppose the man who was unlucky enough to be wounded with a bayonet was usually finished on the spot (Pottle 1929, Chapter Six).

The truth is that finding specific references towards the nature and the resulting damage caused by bayonet wounds in any of the wars of the late-nineteenth century or the two major wars of the twentieth is not as straightforward as one might think. Those who survived were evidently considered as suffering from basic stab wound(s) unless there was something of special note about the case: for example, in 1941 the treatment of a soldier with an accidental bayonet wound in his ischio-rectal fossa that penetrated the base of the bladder (Matthews 1941, 325).

That said, the emphasis in the late-nineteenth- and early-twentieth-century German and other military training manuals for bayonet fighting was, in order of importance, on the usually fatal thrust to the neck area followed by the upper chest and heart, and then to other parts of the body. This was indeed the tenor of the principal bayonet-fighting manual used by the Germans during WW1 (Anon 1908). Contrary to popular opinion, however, a bayonet thrust to the abdomen was to be avoided. While it might be thought such a blow would undoubtedly result in significant internal damage, it was not always so. As Delorme $(1914,148)$ observed with specific regard to abdominal wounds by bayonets and lances, 'Elles sont profondes, sans toujours atteindre l'intestin' ('While these were sometimes deep, they did not always wound the intestines'), implying they were survivable.

The explanation is that the intestines of man and beast are tightly packed and elastic and slithery, and a bayonet 'point' might well slide between them. True, much would depend on the depth and direction of an abdominal thrust, which in the first place requires a man to focus his whole upper body weight in line with his rifle and its fixed 
bayonet on a small target area to be effective while warding off a potential parry. Something difficult to achieve, one might suspect, in the heat of close combat. In addition, the thrust has to be forceful enough to penetrate an enemy's uniform and possibly any accoutrements also before entering the body, and yet not be too deep as a bayonet blade thrust into the abdomen risked being held there by the natural contraction of the stomach muscles. Hence, the direction by Lieutenant Colonel R. B. Campbell, the British Army's bayonet-fighting expert in WW1, that to plunge the bayonet blade through the abdomen was a wasted effort as 'three inches in the heart was quite sufficient' (Jack $1964,227)$. Siegfried Sassoon also noted Campbell's advice to use short stabs and when facing an opponent, to: 'Stick him between the eyes, in the throat, in the chest ... Don't waste good steel. Six inches are enough. What's the use of a foot of steel sticking out at the back of a man's neck? Three inches will do for him' (Sassoon 1931, 17).

What, then, of wounds by that '(E)ngin de torture; une baïonnette à crochets; une arme blanche déshonorée,' the 'Barbarous German bayonet'? To begin with, from the official data for casualty rates as set out above, it might seem rather unlucky for a soldier to suffer any form of bayonet wound in combat during WW1, or if he did so, fail to be rescued and treated in a medical facility. Of course, we simply do not know how many men who suffered a bayonet thrust were killed outright or were bayonetted while lying on the ground when wounded already - a standard technique found in the bayonet training manuals of all nations - or who died while awaiting recovery and subsequent care by the medical services. Burial parties certainly were not interested in how a man died, only his identity. And even if they were interested in his manner of death, the specific evidence for the type of German bayonet used would only become apparent, if at all, through autopsy. Such is suggested by at least one recent forensic study of a wound caused by a typical socalled survival knife, the nearest equivalent in present use to a German sawback bayonet. It was found to cause a distinctive V-shaped wound that caught and could even partly sever bone: but the wound shape and specifically the damage caused was only identifiable through autopsy, and at that through an examination of a wound inflicted on an already naked body (Pollak 1983, 11-20).

Quite simply, in the conditions of WW1, there was simply no need really to determine how a man had died. Nor, in what is an admittedly perfunctory search of the available literature, has it been possible to identify any references to the allegedly egregious wounds caused by the 'barbarous' German sawback bayonet. Certainly, they are not mentioned or alluded to in the official reports regarding the mistreatment of civilians in Belgium and France in the opening months of the war, nor in a collection of accounts recording life at the front at the time. While it is conceded that unread personal diaries and letters and regimental accounts on the allied side of WW1 might refer to such 'barbarous' wounds inflicted by the sawback bayonet, the fact remains that nothing is recorded in the more accessible official records. This is not to deny that the ripping of internal organs and bones might well have resulted from thrusts delivered by a sawback bayonet: but if so, it was not thought worthy of specific record in medical units. More to the point, we should not forget that excluding those units of the Deutsches Heer who were universally armed with sawback bayonets, namely Pionier units and the like and dedicated machine gun units, $6 \%$ or so only of a German attacking or defending force was likely to be armed this way. In which case, wounds or fatalities resulting from their use in close combat must have formed a tiny fraction of the total casualties sustained in such events. 


\section{The demise of the German Sawback bayonet}

Whatever the reality and frequency of wounds caused by sawback bayonets, allied propaganda on their alleged barbarity did its intended damage, leading ultimately to their withdrawal from front-line service in 1917 (Carter 1984, 34-35). The first documented evidence on how this propaganda was hitting home came on 19 July 1915 when the staff of the Bavarian $1^{\text {st }}$ Ersatzbataillon (training battalion) of the $12^{\text {th }}$ Infanterie-Regiment, a unit far from the front line, reported to the Bavarian $4^{\text {th }}$ Infanterie-Brigade:

The allocation of sawback bayonets to replacement units has repeatedly encountered difficulties as men are afraid to move into the field with these. The view has been spread here and elsewhere, and confirmed by returning combatants from the west and east fronts, that those found in possession of such bayonets are shot without any further ado. From the viewpoint of our enemies it seems that these bayonets are not regarded as proper stabbing weapons for combat use, but as instruments of torture contrary to international law. I ask for approval that, instead of these bayonets, the men be issued with those without a sawback and that handsaws be substituted in their place (Ehle 1981, 3/39; see also Carter 1984, 35, Storz 2006, 370). ${ }^{20}$

A copy of this report was sent the next day to the Generalkommando of the Bavarian $1^{\text {st }}$ Armee Korps and from there on 22 July 1915 to the Bavarian War Ministry, with a note that rumours of this type had recently become familiar to the public and the request that action be taken on the matter, the same information then being sent to the General Quartermaster West on 26 July 1915 (Ehle 1981, 3/39). However, no action seems to have been taken regarding the supplying of sawback bayonets to the Deutsche Heer until the winter of 23 January 1917, when the PWM gave out a legal opinion on the matter. This concluded that:

[sawback bayonets] do not violate international law and ... in particular are not to be viewed as weapons suitable for inflicting unnecessary suffering.... We have not been informed here that our enemies really consider sawback bayonets as contravening international law. For this reason they will continue to be issued to troops according to the existing guidelines (Storz 2006, 370).

What the legal advice given to the PWM stated, however, and what troops in the field believed were quite different matters. More specifically, the Bavarian War Ministry noted how the legal opinion of a German lawyer in an office as passed on to a German soldier in the field did not prevent the enemy from holding an opposite view (Storz 2006, 370). The fact remained that by the time this opinion was announced, many Bavarian units at least believed prisoners captured with sawback bayonets had been violently treated or even put to death. Indeed, it was even claimed that an entire platoon of the Füsilier-Regiment Nr. 73 equipped with sawback bayonets had been shot out of hand after capture by the French and that on hearing this news, another unnamed Prussian infantry regiment armed likewise had refused to carry out an order to attack (Storz 2006, 370-371). As it is, although the Füsilier-Regiment Nr. 73 was undoubtedly provided with such bayonets, as a French report of 4 November 1914 confirms (Méry 2016, 297), there is no mention of such an incident in the regimental history (von Szczepanski 1923), nor is anything of the kind mentioned in the memoirs of Ernst Jünger, the regiment's most famous member. Even so, the 
rumours were found convincing enough that on 13 March 1917 , the $12^{\text {th }}$ Infantry Brigade reported:

In all battalions the common view is that the men only unwillingly and with some reluctance take these weapons into the front areas and try to exchange them for non-sawback bayonets, or throw them away or leave them in store. It cannot be verified whether prisoners using sawback bayonets have really been maltreated. (Storz 2006, 371)

Indeed, an anecdote of this kind is reported in Chapter Six of Im Westen nichts Neues (All quiet on the Western Front), the classic German account of WW1 by Erich Maria Remarque, in which Paul Baumer, his central character, states how when he and his Kameraden were off-duty, as it were:

We even overhaul the bayonets - that is to say, the ones that have a saw on the blade back. If the enemy over there catch a man with one of those he is killed outright. In the next sector some of our men were found whose noses were cut off and their eyes poked out with their own saw-bayonets. Their mouths and noses were stuffed with sawdust so they suffocated. Some of the recruits have bayonets of this kind; we take them away and give them the ordinary kind

The truth is, however, that we do not know what front-line service Remarque personally experienced - if any (cf. Bance 1977, especially 371). He served with a reserve unit, the 2. Kompanie Feld-Rekruten-Depot der 2.Garde-Reserve Division, although he was sometimes detached as a schanzarbeiter or 'trench digger', in which capacity 'grenade' fragments wounded him. ${ }^{21}$ Thus, what he describes in a novel published some ten years after the war had ended need be nothing more than hearsay connected to this long-held belief among German soldiers in the fate of those captured with a sawback bayonet. Indeed, the probability that he is reporting hearsay finds support in the absence of any mention at all of the sawback bayonet in other first-hand accounts by German veterans of trench warfare in 1914-1918. For example, the straightforward narrative by E. Jünger (1922), has nothing to say on these weapons, nor does the semi-autobiographical record by W. Flex (1917), or the more philosophical collection of diary entries, etc., presented by Rinding (1925). ${ }^{22}$

Be that as it may, rumours concerning the fate of soldiers captured with sawback bayonets were sufficiently credible that on 25 April 1917, despite the considered opinion of the PWM on the legality of sawback bayonets under international law, the Bavarian War Ministry issued unilaterally an order cancelling any further production by their suppliers (Ehle 1981, 3/40). This decision was undoubtedly connected to a survey among their four army corps and 26 divisions which asked the following three specific questions:

Have you made any observations regarding the maltreatment of prisoners armed with sawback bayonets?

Do the troops hold to the view that prisoners armed with such bayonets are shot or maltreated?

Do the troops in the front lines try to get rid of this weapon? (Storz 2006, 371).

The Cavalry Division was the only formation to respond 'Yes' to the first of these questions, but all gave this same 'Yes' to the other two. 
Faced with such an overriding belief among their men under arms on the fate that awaited any German soldier captured with a sawback bayonet that the Bavarian War Ministry sent the following memo on 7 July 1917 to the 'Herrn Chef des Generalstabs des Feldheeres' in Berlin asking:

The [Bavarian] War Ministry asks the General Staff to give their favourable consideration to the following:

(1) The abolition of the sawback bayonets for use by infantry soldiers,

(2) To substitute instead for these troops (but excluding the pioneers) collapsible saws (Norris (sic) saws).

... [There are] no clear indications that troops equipped with sawback bayonets were treated any worse when captured than other prisoners ... [but such is the] 'generally accepted and universally confirmed view of the front troops on the dangers of possessing this weapon' that it was the best course of action to adopt (Ehle 1981, 3/39).

In fact, having on 25 April 1917 already suspended unilaterally the supply of sawback bayonets to its infantry contingents, on 6 August 1917, the Royal Bavarian Ordnance department not only reiterated that order but added that any such bayonets in stock were to be issued to pioneer units only (Ehle 1981, 3/40).

It cannot be coincidental that within a few days, Ludendorff, First Quartier-Master General of the Deutsches Heer took a hand in the matter. On 17 August 1917, he reported to the Prussian High Command:

(1) The view that the sawback bayonet is considered by the enemy to be contrary to international law and that a captured person carrying such a weapon is punished by death is widespread among NCOs and their men.

(2) Men often seek to get rid of or exchange this weapon before entering combat. I, therefore, ask that you discontinue the production of the sawback bayonet and gradually replace those ones at the front with bayonets without a sawback.

The Bavarian War Ministry suggests that the troops be equipped with a large number of collapsible saws (Noris saws). I request your opinion on this. From here there are no objections to the suggestion (Ehle 1981, 3/40)

On 17 September 1917, the PWM bowed to the inevitable and ordered that sawback bayonets in frontline service should - wherever possible - be gradually replaced by those without a sawback (Storz 2002, 372). It took another month, however, for the Bavarian War Ministry to decide on how this was to be done with an order issued on 17 October 1917 stating:

(1) By agreement with the Oberheeresleitung and the Imperial Prussian War Ministry, sawback bayonets in front-line service will be exchanged for bayonets without a sawback. Those formations not in front-line service are excused compliance ... [I]nfantry and Jägerbataillone at the front are to be given in place of the discontinued sawback bayonets another 12 (i.e. making a total of 
24) collapsible saws [per Bataillon]. With regard to the replacement of the sawback bayonets and the delivery of the saws, according to the K.M.E. [= Königlicher Militärerlaß = Royal Military decree] of the 24.06 .15 no. 55749, saws from the Möbelhaus Noris Company in Nuremberg will be brought in and delivery effected according to the requirements of the field stations as reported by the Etappe-inspection (= rear-echelon command) to the Bavarian Armoury in Munich, which is where the discontinued sawback bayonets will be sent in exchange.

(2) With regard to the replacement units and the activation of new formations, the men shall henceforth be armed only with bayonets without a sawback. Replacement troops may be armed with sawback bayonets; but it is important to ensure that the stock of bayonets without sawbacks [for these units] does not fall below $50 \%$ of the total available (Ehle 1981, 3/40).

Given the somewhat ambiguous nature of this communication, the following confirmatory memo was sent to the administrative section of the Bavarian $1^{\text {st }}$ Army Corps on 5 November 1917:

In future distributions of the $\mathrm{S.98/05}$ by the Bavarian Armoury, $50 \%$ of the replacement troops will receive $5.98 / 05$ with sawbacks. These $5.98 / 05 \mathrm{mS}$ are to be used by the replacement troops while in garrison. A garrison stock of S.98/05mS will be established. Any existing S.98/ 05 without a sawback are to be stored in the respective Bataillon or detachment's armoury to be issued to the men just before they leave for the front (Ehle 1981, 3/41).

The progressive removal of sawback bayonets from front-line service thus commenced. The numbers involved were certainly impressive. For example, the Bavarian War Ministry had already reported on 29 May 1917 that including those in stock and with reserve and other non-combatant units, they held 29,981 S.98/05 mS and 999 S.84/98 mS, as well as various other sawback bayonets, which together accounted for almost $24 \%$ of the bayonets then 'in service' (Storz 2006, 372). By 31 October 1917, the PWM could report that $900,000 \mathrm{S.98/05} \mathrm{mS}$ and 95,900 of the obsolete $S .98 \mathrm{mS}$ had been returned to stock (Storz 2006, 372). These were not, however, to be scrapped, as was stressed in a communique issued by the PWM on 3 December 1917:

Following the decree of 16 September 1917 ... according to which those sawback bayonets at the front are to be gradually exchanged for bayonets without a sawback, the following has been agreed with the chief of the general staff of the field army on what to do with these sawback bayonets.

Those formations in the Etappe, etc., not in front-line service will keep their sawback bayonets. These formations will continue to be supplied with sawback bayonets. Garrison troops, prisoner-of-war guard battalions in the interior, etc., are to exchange their bayonets without sawbacks for those with sawbacks.

Replacement troops will be equipped with bayonets with sawbacks for $50 \%$ of their total requirements. The bayonets without a sawback above this number are to be returned according to instructions given by WUMBA [= Waffen- und Munitionsbeschaffungsamtes = 'Office for coordinating weapons and munitions production'].

It is particularly emphasized that no bayonets with a sawback may be supplied to troops in the front line, and that the troop commanders must be held responsible for this matter. 
Similarly, only bayonets without a sawback may be given to the replacement troops in the front line, as well as to new formations of troops for front line service ... (Ehle 1981 3/41).

To which we might add the survival today of at least one S.98/05aAmS marked to the Deutsche Reichpost for use by their Postschutzen section (Wheeler 1999, 56 and, 67), presumably replacing an earlier standard S.98/05 now needed for front-line services.

As WW1 reached its peak in the winter of 1917/1918, though, the PWM, presumably conscious of the increasing need to preserve stocks of steel, etc., decreed on 6 January 1918 that:

Experiments by employees with the grinding down of the sawback on the S.84/98 and S.98/ 05 with sawback have shown that these bayonets can be transformed to bayonets for combat use without their sawback.

The Waffen-und Munitions-Beschaffungsamt (i.e., WUMBA) has therefore been commissioned to issue an order for the grinding-down of the sawback on the designated bayonets without delay.

The altered bayonets are to be named as:

Bayonet 84/98 S.Abg.,

Bayonet 98/05 S.Abg.

The selected abbreviation 'S.Abg.' means 'sawback ground down'.

There is no limit to the use of these bayonets; they can be delivered also to troops in the front line. To initiate the change, the Waffen-und Munitions-Beschaffungsamt will replace those examples of recently received examples of bayonets $84 / 98$ and $98 / 05$ with a sawback which still exist in the hands of the field and occupation troops, as included in the decree of 3 December 1917, No. 725/11. 17. A2, and gradually exchange these for bayonets without a sawback (or, for example, a bayonet S.Abg).

The provision provided in the aforementioned decree of bayonets with a sawback to the formations not in the first line, but in the Etappe (i.e., rear echelon troops), or in garrison, or prisoner-of-war guards in the interior, or replacement troops, etc., remains in force as long as bayonets with a sawback are used for the purpose of self-defence only (Ehle 1981, 3/42). ${ }^{23}$

The procedure left a prominent 'hump' between the blade ricasso and the new blade back. Figures 8 and 9, and the few surviving sawback bayonets that remained with their saws intact after 11 November 1918 were presumably in the main included in the piles of edged weaponry collected under the auspices of the Inter-Allied Military Control Commission after it began work formally on 10 January 1920 (Shuster 2006, 39-40, with 169). As such, they were among the $6,462,198$ edged weapons of war of all kinds recorded for disposal by that commission on 1 October 1921 (Storz 2006, 373), destined for destruction in the melting pot rather than re-use elsewhere. In this way, the long association of the sawback bayonet with the various German states came to an end, except for those already souvenired to feature in today's museum and private collections, and in auction and other sales, as: 'weaponry so barbaric it was banned under the Geneva Convention for inflicting incredible pain on soldiers'. 


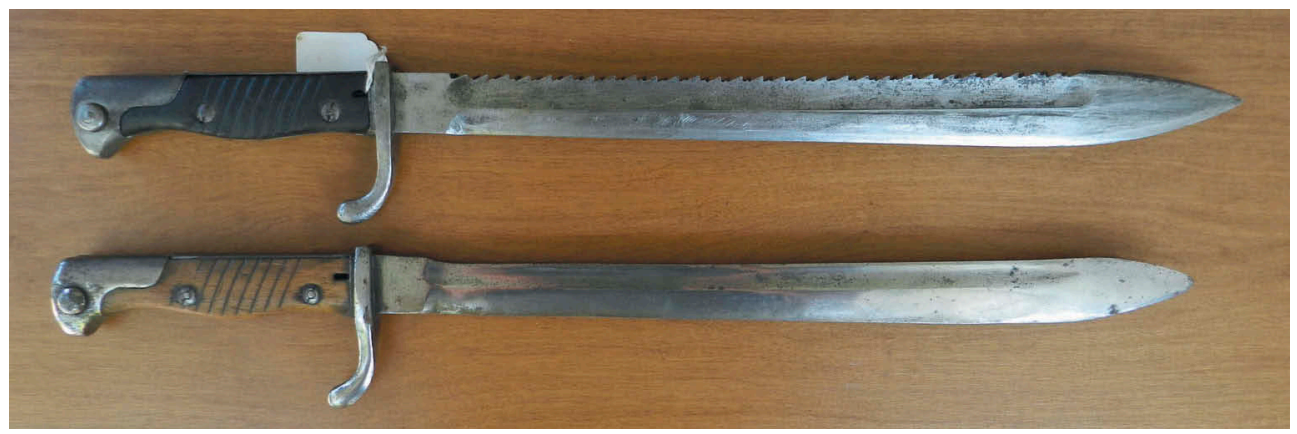

Figure 8. An S.98/05nA.mS (above) with a S.98/05nA.S.Abg (below): author's photograph.

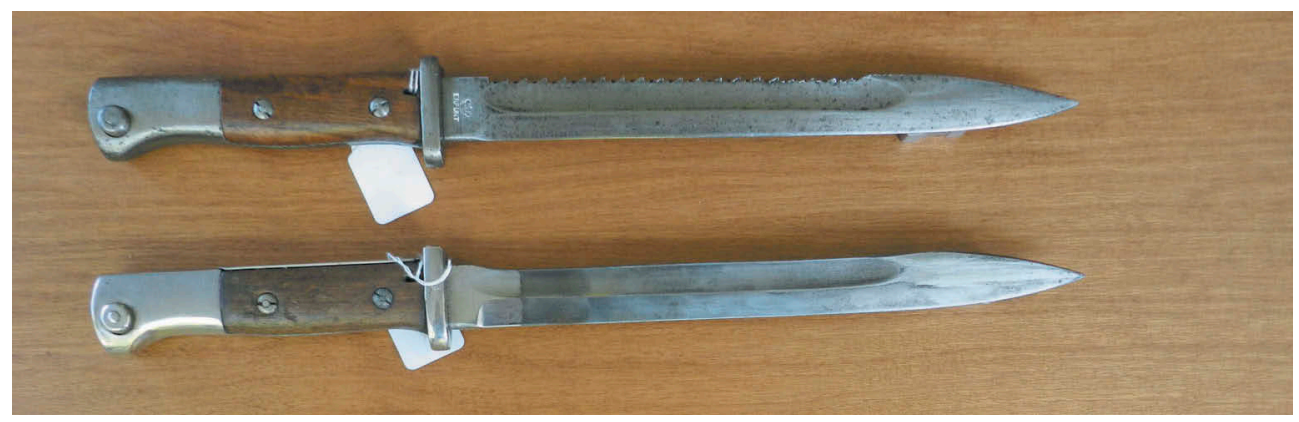

Figure 9. An S.84/98nA.mS (above) with an S.84/98nA.S.Abg (below): author's photograph.

\section{Discussion}

As we have seen, in the first few weeks of WW1, the German sawback bayonet attracted to itself an unenviable reputation as a weapon designed with specifically barbarous intent. This was despite its real function as a tool-cum-bayonet for use primarily by sappers and the like in the cutting and clearing of brushwood and so forth for various purposes, and perhaps even for pure butchery. As we have shown, this particular function of a sawback bayonet was familiar to those European armies which had previously employed similar items. However, within months of the outbreak of WW1 the repute of the sawback bayonet issued to the Deutsches Heer as a purposely designed vicious weapon of war matching the innate barbarism of the 'Hun' had sufficiently impressed itself on the public mind to lead quickly to its condemnation as such at that time, and - as we have seen gain a notorious reputation that survives today in what might best be explained as a 'folk memory'.

This reputation must surely help explain the relatively large numbers of these weapons that survive today, as evidenced by their regular appearance in online and other auction sales compared with the relatively limited numbers issued during wartime. Consider, for example, a listing made by this writer from sales and other sites of unit-marked examples of the S.98/05. From a total of 181, sawback versions number 95 . Once we take into account that orders unit-markings were dispensed with during wartime, as confirmed by the PWM on 2 November 1916 (cf. Wacker and Görtz 2005, 175), these figures indicate a survival rate far beyond their actual $6 \%$ production numbers for the pre-1916 period 
when the unit marking of weapons effectively ceased. Evidently, sawback bayonets were especially favoured war souvenirs by members of the allied forces as tangible reminders of the barbaric 'Hun', as no other explanation accounts for this high survival rate.

More pertinent here, though, is to see how the insidious effect of the various enquiries by Belgium and other countries into the allegedly innate barbarous behaviour of the Imperial Germany army and in particular in this regard, its weaponry fed into the morale of that army. It cannot be coincidental that references in the Allied countries to the use of the 'barbaric' sawback bayonet by members of the Deutsches Heer commenced almost immediately after WW1 began. Likewise, it is surely not coincidental that by the summer of 1915, even German soldiers stationed behind the front line were well aware of the alleged fate facing those found with a sawback weapon. Even so, the PWM chose not to withdraw the sawback bayonet from regular front- and rear-line service until almost two years later. Quite why this long delay intervened is uncertain but might perhaps be due to the increasing availability for trench raids after 1916 of the S.84/98nAmS, which brought to the fore once again the belief among Soldaten that those found with such weapons faced summary punishment.

\section{Notes}

1. 'An instrument of torture, a bayonet with teeth, a dishonourable weapon'. For the origin and context of the quote see below.

2. The principal exception to this regulation was a concession announced on 22 March 1897 that the headgear of the principal contingents of the new Imperial army would carry both the new 'national' black-white-red cockade and a second cockade beneath this coloured to identify the parent state of the relevant contingent.

3. The prefix 'I' used to indicate weapons designed for German infantry use was dropped on 15 March 1905: cf. Ehle (1981), 3/1. Thereafter, the common abbreviation for rifles was ' $G$ ' or 'Gew.', for 'Gewehr' (with 'Kar' for Karbine used for carbines), while for bayonets and swords alike it was ' $S$ ' for Seitengewehr, literally 'sidearm', the official designation for all forms of personal edged weapons.

4. Much of the German documentation relevant to this article is preserved in the Bayerisches Hauptstaatsarchiv, Abteilung IV: Kriegsarchiv, München. However, rather than give the lengthy file number, etc., for each individual record, reference is made to the more easily accessible excerpts from these as published in transcript or in facsimile mode in Ehle $(1981,1986)$ as translated by the author.

5. It has not been possible to establish when this term was first employed. It does not appear in Farrow (1918).

6. Patented in Germany as 86,365 on 30 October 1895 , and in Great Britain as 21,546 on 13 November 1895, confirmed 28 December 1895, the method of fitting evidently inspired the development of the nose-cap and boss bayonet attachment system used with the P.1907 (SMLE) rifle as patented in Great Britain 11 July and confirmed on 19 August 1901: cf. Ballard and Bennett $(2017,271, \mathrm{n} .3)$.

7. The 'lappen' are in archaeological terms skeuomorphs, reflecting the cut-down muzzle-rings of the first bayonets altered for use with the Gew.98.

8. Almost all German bayonets were dated on their blade-spine with the last two digits of the year they were inspected prior to service issue.

9. Note, however, that some S.98/05 represent 'transitional' models, in having a Schutzblech and 'high ears', or conversely no Schutzblech and 'low ears': see Carter (1991), 28-30.

10. Those bayonets that copied this knife-style almost immediately were the Austrian Mannlicher Model 1895 and the Swedish Model 1896. 
11. In 1908, the Imperial Cavalry began to re-arm with the Kar.98 AZ ('Aufpflanz-undZusammensetzvorrichtung' = 'with bayonet attachment and piling stack'), although only Luftschiffer units were provided with a bayonet for this, in the form of the kS 98: Storz $(2006,66)$.

12. It will be shown elsewhere that this order was connected directly with the decision in late 1914 to arm cavalry units as a temporary measure with the $S .14$ and the first Aushilfseitengewehre, or 'Ersatz' bayonets.

13. In the Weimar period, ex-WW1 S.84/98nA became the standard sidearm of the Reichsheer, and from $1934 / 35$ to 1945 , newly made examples became the regular issue bayonet of the Third Reich's Wehrmacht: cf. Carter (1991, 184-190), with Wheeler (1999, 76-101).

14. The term 'atrocity' and its cognates are avoided here in an attempt to avoid over-emotive language for what were, in law, war crimes.

15. Author's translation.

16. Presumably, a reference to Article 23(e) of the Annexe to the 1907 Hague Regulations Concerning the Laws and Customs of War on Land, forbidding the use of 'arms, projectiles, or material calculated to cause unnecessary suffering'.

17. Author's translation.

18. Balck, a Generalleutnant by 1918, and father of the better-known WW2 General der Panzertruppe Herman Balck, was less praising of the bayonet in combat after his experiences in WW1: cf. Balck (1922) passim.

19. The use of cold steel in all its forms by cavalry units in direct combat probably reached its apogee in this year, with the claim it was the year in which lance 'had the widest distribution it had ever enjoyed' in European cavalry conflict: Strachan (1983), 84.

20. This and all following translations from German are by the author.

21. Remarque's military service is conveniently summarized online at: https://www.remarque. uni-osnabrueck.de/. Accessed 9 September 2019.

22. A necessary corollary here is how remarkably few personal German language accounts of WW1 were published in the postwar period.

23. In Saxony this work was performed by six trained 'war invalids (one leg)': Storz (2006, 372).

\section{Acknowledgments}

The author thanks the following for their direct and indirect help in the preparation of this article: Philip Andrade, John M. Ballard, David Filsell; Dominique Kassab Tezgör; and the Inter-library Loan section of the Bilkent University Library. The research for the article has benefitted greatly also from 'chats' with various members of two on-line discussions groups: the Great War Forum and the Gunboards Forum.

\section{Disclosure statement}

No conflict of interest is known to the author.

\section{Notes on contributor}

Julian Bennett is an Associate Professor in the Department of Archaeology, ihsan Doğramacı Bilkent University, Ankara, Turkey. A Fellow of the Society of Antiquaries, his professional field of study is the Roman army and the Roman provinces. His non-professional interest is the archaeology of the infantry weapons used in WW1, especially the bayonets, on which he has authored and co-authored three previous articles. Author Information (ORCID 000-0002-6529-423X) 


\section{References}

Anon. 1869. "The Soldiers Side-Companion." Punch, 57 August 7

Anon. 1932. "Casualties in War." The Indian Medical Gazette, February 6-7. 91-103.

Anon. 1908. DVE 166, Vorschrift fr das Gewehrfechten der Infanterie. Berlin: Prussian War Ministry.

Balck, W. 1911. Tactics I (Translated by W.Kruger). Fort Leavenworth: United States Cavalry Association.

Balck, W. 1922. Entwickelung der Taktik im Weltkriege. Berlin: R. Eisenschmidt.

Ballard, J. M., and J. Bennett. 2017. "An Investigation of the Weights of Pattern 1907 Bayonets Made in the UK around the First World War Period." Arms \& Armour 14 (2): 206-222. doi:10.1080/ 17416124.2017.1379786.

Bance, A. F. 1977. "“Im Westen Nichts Neues": A Bestseller in Context." The Modern Language Review 72 (2): 359-373. doi:10.2307/3725082.

Beyer, J. C. 1962. Wound Ballistics. Washington, DC: Office of the Surgeon General, Dept. of the Army. Bryce, J. 1915. Report of the Committee on Alleged German Outrages. London: Eyre and Spottiswoode. Buchholz, F., J. Robinson, and J. Robinson. 2014. The Great War Dawning: Germany and Its Army at the Start of World War I. Vienna: Verlag Militaria.

Carter, A. J. 1984. The German Bayonet 1. Norwich: Tharston Press.

Carter, A. J. 1991. The German Bayonet 2. Norwich: Tharston Press.

Carter, A. J. 1994. The German Bayonet 4. Norwich: Tharston Press.

Cooreman, G. F. M. 1915. The Martyrdom of Belgium. Official Report of Massacres of Peaceable Citizens, Women and Children by the German Army: Testimony of Eye-witnesses. Baltimore: W. Stewart Brown.

Cranz, C., and K. R. Koch. [1898]1899. "'Schwingungen in verticaler Ehene bei horizontal gehaltenem Gewehr. A. Gewehre vom Typus des Mausergewehrs. Modell 71'." Abhandlungen, Denkschriften und Reden der K. Bayer. Akademie der Wissenschaften. 19:745-775.

Cranz, C., and K. R. Koch. [1901]1902. "Untersuchung über die Vibration des Gewehrlaufes (Schluss): II. Schwingungen in horizontaler Ebene." Abhandlungen, Denkschriften und Reden der K. Bayer. Akademie der Wissenschaften. 21:557-574.

Delorme, E. 1914. Précis de Chirurgie de Guerre. Paris: F.Alcan.

Ehle, F. 1981. Die Wichtigsen Vorschriften über die Seitengewehre der Truppen zu Fuss des Königreichs Bayern. Rosenheim: privately published.

Ehle, F. 1986. Die Seitengewehre der Truppen zu Pferde und die Lanzen im Königreich Bayern nach zeitgenössischen Dokumenten und Vorschriften. Rosenheim: privately published.

Farrow, E. S. 1918. A Dictionary of Military Terms. New York: T.Y.Crowell.

Flex, W. 1917. Der Wanderer zwischen beiden Welten: Ein Kriegserlebnis. Munich: E.S.Bect'sche Verlagsbuchandlung.

Franz, R. W. A. 1994. Preussisch-deutsche Seitengewehre 2. Schwäbisch Hall: Journal-Verlag Schwend. 1807-1870.

Franz, R. W. A. 2000. Preussisch-deutsche Seitengewehre 4: 1871-1883. Schwäbisch Hall: Journal-Verlag Schwend.

Franz, R. W. A. 2001. Preussisch-deutsche Seitengewehre 5: 1884-1897. Schwäbisch Hall: Journal-Verlag Schwend.

Gilchrist, H. L. 1928. A Comparative Study of Casualties from Gas and Other Weapons. Edgewood MD: Chemical Warfare School.

Guthrie, G. J. 1848. "Lectures on Some of the More Important Points in Surgery." The Medical Times. 17/436:305-308.

Henry, H. J. 1915. "Letters." accessed 08 September 1919. http://net.lib.byu.edu/estu/wwi/memoir/ henry/Henry.htm:

Home, J., and A. Kramer. 2002. German Atrocities, 1914: A History of Denial. New Haven, CT: Yale University Press.

Jack, J. L. 1964. General Jack's Diary 1914-1918: The Trench Diary of Brigadier-General J. L. Jack. London: Eyre \& Spottiswoode.

Jünger, E. 1922. Stahlgewittern. Aus dem Tagebuch eines Stoßtruppführers. Berlin: Verlag von E.S. Mittler \& Sohn. 
Koetggen, J. 1916. Die Deutsch-Amerikanischen Arbeiter und das Kriegs-Problem. Chicago: Der Deutschen Sprachgruppe der Sozialistischen Partei der Vereinigten Staaten.

Koetggen, J. 1917. A German Deserter's War Experience. New York: Huebsch.

Lipkes, J. 2007. Rehearsals: The German Army in Belgium, August 1914. Leuven: Leuven University Press.

Macpherson, W. G. 1924. History of the Great War Based on Official Documents, Medical Services General History, 3. London: Macmillan.

Macpherson, W. G., and T. J. Mitchell. 1924. History of the Great War Based on Official Documents, Medical Services General History, 4. London: Macmillan.

Marre, F. 1916. Des armes dèloyales des allemands. Paris: Bloud et Gay.

Matthews, D. N. 1941. "Penetrating Bayonet Wounds." Journal of the Royal Society of Medicine. 34:325.

McGill, P. 1919. The Diggers: The Australians in France. London: Jenkins.

Meredith, J. 2004. Understanding the Literature of World War I: A Student Casebook to Issues, Sources and Historical Documents. London: Greenwood Press.

Méry, C. 2016. The German Bayonet 1898-1945. Brazey en Plaine: Editions Du Brevail.

Mitchell, T. J., and G. M. Smith. 1931. The Official History of the War, Medical Services, Casualty and Medical Statistics. London: HM Stationary Office.

Morgan, J. H. 1915. A Dishonoured Army: German Atrocities in France: With Unpublished Records. London/New York: Spottiswoode \& Co/Leonard Scott Publication.

Oberleutnant Hein. 1901. Das kleine Buch vom Deutschen Heere. Kiel/Leipzig: Lipsing und Tischer Verlag.

Ogilvie, F. B. 1915. Stories and Letters from the Trenches. New York: J.S. Ogilvie publishing company.

Petit, H. 2018. https://www.dailymail.co.uk/sciencetech/article-5194159/Barbaric-German-WW1armour-weaponry-set-auction.html accessed June 1519.

Pollak, P. 1983. "Befundmuster bei Verletzungen durch "Überlebensmesser"." Archiv für Kriminologie. 183:11-20.

Pottle, F. A. 1929. Stretchers: The Story of a Hospital Unit on the Western Front. New Haven: Yale University Press.

Rinding, R. 1925. Aus dem Kriege. Frankfurt am Main: Literarische Anstalt Rutten and Loening.

Roy, R. 1914. Répertoire Alphabétique de Termes Militaires Allemands. Paris: Nancy/Berger-Levrault.

Sassoon, S. 1931. Memoirs of an Infantry Officer. London: Faber.

Schulyer, W. S., J. F. Morrison, C. Reichman, and P. C. March. 1906. Reports of Military Observers Attached to the Armies in Manchuria during the Russo-Japanese War, Part I. Washington DC: Government Printing Office.

Shuster, R. J. 2006. German Disarmament after World War I: The Diplomacy of International Arms Inspection, 1920-1931. London and New York: Routledge.

Stone, J. 2012. "The Point of the Bayonet." Technology and Culture 53 (4): 885-908. doi:10.1353/ tech.2012.0149.

Stone, J. 2016. "A Proxemic Account of Bayonet Fighting." Journal of Strategic Studies 39 (7): 10231043. doi:10.1080/01402390.2015.1125338.

Storz, D. 2006. M98 Rifle and Carbine: M98 Firearms of the German Army from 1898 to 1918. Wien: Verlag Militaria.

Strachan, H. 1983. European Armies and the Conduct of War. London: Routledge.

Szczepanski, M. 1923. Erinnerungsblätter aus der Geschichte des Füsilier-Regiments Generalfeldmarschall Prinz Albrecht von Preußen (Hann.) Nr. 73 während des Weltkrieges 19141918. Oldenburg in Oldenburg: Stalling.

Vorontova, V. V., and D. V. Vorontova. 2015. Штьіки Германии Модели Pfm 71/98, S.98/02, 5.98/05. Moscow: Альбом (Album).

Wacker, A., and J. Görtz. 2005. Handbuch Deutscher Waffenstempel auf Militär- und Diensthandwaffen 1871-2000. Herne: VS Books.

Wheeler, G. 1999. Seitengewehr: History of the German Bayonet 1919-1945. San Jose, CA: R.J. Bender.

Wintringham, T., and J. N. Blashford-Snell. 1973. Weapons and Tactics. Baltimore: Penguin Books. 